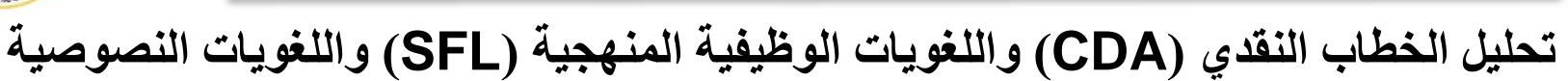 لتوضيح كيفية عرض أزمة فيروس كورونات(كوفيا 19DA)
}

عاصم مهدي الهلالي م. دعاء حافظ حسين

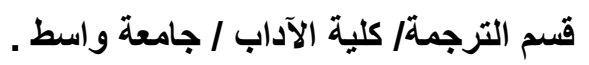

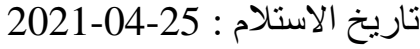

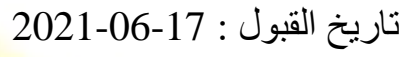

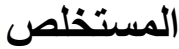

يتناول هذا البحث موضوع الدراسة الحالية بشكل انتقائي من خلال اعتماد تحليل الخطاب النقدي (CDA) و اللغويات الوظيفية المنهجية (SFL) و اللغويات النصوصية لتوضيح كيفية عرض أزمة فيروس كورونا(كوفيد 19) الحالية في وسائل الإعلام العربية ، تقرير في الجزيرة كدراسة حالة. من خلال تطبيق تحليل الخطاب النقدي و اللغويات الوظيفية المنهجية، يكون الباحث قادرًا على معرفة الأيديولوجيا و المواقف التي تتبناها هذه القناة التلفزيونية التي تعمل كأساس لاختيار الخيارات و الاستر اتيجيات الأساسية لبنية الخطاب المحددة لتمثيل التعدي ، أب المعنى الفكري المضمّن في النص.

ينصب اهتمام الدراسة بصورة رئيسية على توضيح أنواع العمليات الفعلية (سواء كانت عقلية أو مادية أو علائقية أو سلوكية أو لفظية) المستخدمة في التقرير المأخوذ من الموقع العربي لقناة الجزيرة الفضائية من أجل إعطاء وصف للطريقة التي يتم من خلالها تقديم ووصف جائحة كورونا المستجد كمشارك ووصف الأدوار المسندة إليه. بعد إجر اء التحليل ، استتنج أنه من أجل عكس التأثير الفعال والقوي الذي أحدثه المرض على العالم بأسره ، اختار كاتب التقرير الاستثمار في الاستخدام المتكرر لنوع أفعال العمليات المادية أكثر من غير ها من انواع العمليات الفعلية لتوضيح

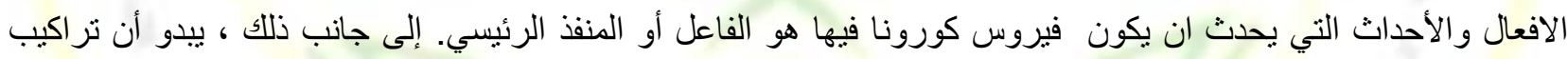
خطاب التقرير قد تم اختيار ها عن قصد ليس لنقل المواقف العاطفية للكاتب ولكن لإعلام القارئ و إنشر اكه عاطفياً في تفاعلات النص لتسليط الضوء على العو اقب الخطيرة للمرض على العالم و على الحياة الاجتماعية والصحية و الاقتصاد ية للافر اد.

كلمات مفتاحية : فايروس كورونا ، تعدي ، تحليل ، عملية مادية ، عملية لفظية ، ايديولوجيا 


\title{
Coronavirus in the Arab Media: A Transitivity Analysis of Aljazeera Arabic Website
}

\author{
Asim Mahdi Al- Hilali, university of Wasit, translation department \\ Email: asimmahdi@uowasit.edu.iq \\ Mob: 07827044455 \\ Dua'a Hafidh Hussein, university of Wasit, translation department \\ Email: duaaha522@yahoo.com \\ Mob : 07710926788
}

Receipt date: 2021-04-25

Date of acceptance: 2021-06-17

\begin{abstract}
The present paper approaches the topic of the current study eclectically by adopting critical discourse analysis(CDA), systemic functional linguistics(SFL) and corpus linguistics to show how the present crisis of coronavirus(covid19) is presented in the Arab media, a report in Al-Jazeera as a case study. Through the application of CDA and SFL, the researcher would be able to figure out the ideology and attitudes adopted by this TV channel.
\end{abstract}

Mainly, the concern of the study is to illustrate what types of verb processes are utilized in the report in order to give an account of the way the novel corona pandemic as a participant is introduced and described and what roles are assigned to it .

After carrying out an analysis, it is concluded that to reflect the influential and powerful effect that the disease brought about, the writer of the report opted for investing the frequent use of the type of material process verbs to demonstrate actions and events in which Coronavirus is the major actor or agent. Besides, the report's discourse structures are intentionally selected not to convey the writer`s sentimental attitudes but to inform and emotionally involve the reader in the text interactions.

Key Words: Coronavirus, Transitivity, Analysis, Material process, Verbal process, Ideology 


\section{INTRODUCTION}

Arab states, governments and peoples were shocked on hearing of the emergence of coronavirus a novel and cureless disease with all the possible damaging effect on their life which is already replete with all kinds of problems on the various levels whether in politics, social life, public services, education, health care systems, etc. Since its emergence and spread in Wuhan, China as an epidemic threatening the whole world with eminent catastrophe if no serious and urgent measures are taken to combat it on the one hand up to the spreading out of the disease and turning into a pandemic endangering the whole human economic and social life to face paralysis and slow death on the other.

Arab communities are keen to follow up the developing stories of the virus and obtain enough information about what is going on in order to take sufficient precautions and measures to shield themselves against this intruding incomer. Here, mass media come into play and try to utilize the emerging event to foreground some participant and events and at the same time background others. This is normally performed to be in line with the general policy of the specific mass media and to reflect the vision and implement the main goals entrusted with by the financing or sponsoring party whether be it a government an institution or an individual.

Obviously, the people following Aljazeera know for sure that this channel tends to manipulate and reconstruct news stories in a way that serves its general policy through linguistic and visual strategies and even the channel`s correspondents, who are assigned with writing reports on various events, are not granted freedom to convey factual details on world news , rather, they have to understand and fully abide by the guidelines set by the administration and reflect them in their reports and newsletters .

The ideology of the channel is, therefore, considered the cornerstone in shaping the textual content, framing realities and even creating new relevant ones. The issue of corona is no exception ,since it has become the focus of mass media and people across the world and their major focus of interest.

Aljazeera works within the borders of a country that has his own political alliances and aims to maintain its relations with the influential powers of the world in order to protect and sustain its national interests . 
Accordingly, the sponsoring state of Aljazeera (Qatar) would utilize all its media to propagate a press message which is in harmony with the ideological attitudes of its allies and friends. Mass media in America and Europe, the major allies of Qatar tend to create a horrible effect on their audience both inside And outside their own countries .

In part, the intended aims of creating and magnifying the risk of the pandemic remains unknown, though all that can be said about this particular topic is that there are hidden and undeclared political, economic agendas lying behind this campaign and Aljazeera which works within the political reality of being an American and European satellite country has to observe the rules imposed by the government and never overlook red lines drawn. Hence the way it constructs coronavirus exaggeratingly represents a sort of swimming with the stream of the dominant mass media and a mere echo of their voices.

Yet, it should be noted that the message, away from the hidden agendas, is honestly rendered to audience, since the disease is really fatal and serious and this fact should be honestly conveyed to people to take the necessary prevention measures, a point which partly serves in justifying the channel`s and its news and reports` teams`linguistic and lexical choices.

It goes without saying that media has the power to reshape their audience minds and assist in constructing new social realities so undertone certain events and accentuate others harnessing the set of language choices available in order to fulfill the ideological motivation(s) of the producer(s) .Much of what is said or written is ideologically motivated .Ideologically based language choices are broadly used to serve power and domination objectives and it is obvious that reporters mostly resort to opting specific words and not others based on the ideological stand they adopt or are required to take and ingrain in their audience minds. Thus " there are always different ways of saying the same thing and they are not random, accidental alternatives. Differences in expression carry ideological distinctions and thus differences in representation" (Fowler, 1991:4).

This paper is an attempt to figure out the way coronavirus is presented in Aljazeera 's coverage of the novel disease and what ideological linguistic tools are utilized to present events related to it. The salient aspect the study would focus on is how ideational meaning is realized in the selected sample text through transitivity. Meanings related to the way world experience is represented is the concern of the ideational metafunction. Accordingly, the present paper is focused on finding out what grammatical resources are used to represent coronavirus through the 
known representational strategies of actions and what roles are ascribed to the disease. This would involve the various processes of acting, speaking and even simply" In particular," the existing - or not, as the case may be" (Haig 2011: 20).The present paper will answer the following questions:

1-How the image of coronavirus has been constructed in Aljazeera sample text?

2-What roles are attributed to coronavirus in Aljazeera sample text? Besides, how the ideational metafunction introduced by Halliday is constructed in the text?

Along with the transitivity analysis carried out in the paper, an eclectic approach of CDA is adopted whereby aspects such as collocational restrictions and lexical choices are investigated . Additionally, the paper draws on the approaches introduced by well-known scholars specialized in the field of CDA and PDA like(Van Dijk 1997), (Fairclough 1995 ,2003) and others.

\section{HALLIDAY'S MODEL OF LANGUAGE AND DISCOURSE}

Systemic functional Grammar(SFG) came into being in the 1960s. It was developed by the wellknown linguist, M.A.K. Halliday ,as a theory of language. In 1985 and 1994,his book entitled" An Introduction to Functional Grammar" was published. In this book, he indicates that his theory is based on the functional tradition which first appeared in Europe and on Firthian system structure theory, and derives from jelmslev in its more abstract principles and takes ideas from Prague school(Halliday, 2000:52).

According to Halliday, Language is considered by Systemic Functional Grammar(SFG) ,which approaches language from a social perspective, as a set of meaning resources whereby people become able to interact with each other in situationally and culturally diverse contexts. He states that SFG is a grammatical theory whose major concern is the study of discourse semantics (Halliday ,1994: 15).So, when we say that grammar can be functionally interpreted, we highlight its role as a meaning construing resource.

Halliday also refers to three types (metafunctions,) of meaning through which a distinctive meaning can be interpreted, these are: ideational; interpersonal; and textual (ibid: 35). These metafunctions are a reflection of the world that embraces varied aspects and expresses the various meaning modes of clauses. The ideational metafunction is concerned with organizing the personal experience of the language producer of the world. It subsumes two functions: experiential and logical. Experiential function means that language is a means for expressing external world 
experiences (such as: things, events qualities, etc.) and internal world experiences (such as: thoughts, beliefs, feelings, etc.). Whereas logical function means that the logical relations holding between any meaning units are expressed through language.

The interpersonal metafunction is concerned with linguistic exchanges. That is to say, its main concern is the social world, and the kind of relationship between text producer and its receiver. As for the textual metafunction, it is argued that it is concerned with the verbal world and what messages are sent by clauses.

This triad of metafunctions together form the discourse semantics of any text and their world of realization is the lexicogrammar. According to Halliday $(1978,1994)$, there is a particular system through which each metafunction can be realized and is associated with the situational aspects of register.

Matthiessen (1995) states that SFG sees language as consisting of several levels including semantics, context, lexicogrammar and phonology/graphology. SFG, according to him, views languageasa resource of several levels, namely, context, semantics,

lexicogrammar and phonology/graphology . Phonology/ graphology stands for the expression level, the physical realization of the lexicogrammar stratum and the latter is the level through which the stratum of discourse semantics is realized.

These three strata correspond to three hierarchically arranged strata of context: the context of situation (i.e., what is going on in the specific situation in which the text occurs) and it can be analyzed through register analysis of field, tenor, and mode); the context of culture (i.e., the wider context of the text); and ideology.

Using SFL in CDA can be implemented in two different ways. We can have a macro-analysis in which a particular ideology such as discrimination, religious intolerance, xenophobia, sectarianism or the like is analyzed and then the realization of such ideological issues are traced and investigated through the various strata. On the other hand, a text/corpus can be the point of departure and then a down-top analysis of the various strata can be conducted - to make inferences about the ideology which influenced its productionl (Heig 2011: 21). The first approach looks more subjective and too judgmental and thus we opt for the latter approach in our paper. 


\section{THE SIGNIFICANCE OF TRANSITIVITY}

According to Halliday and Matthiessen(2004), transitivity represents the grammar of experience. Through c categorizing happenings going on in the internal world, experiences and thought into a number of process types, transitivity offers a system to express them. This, accordingly, illustrates why and how it differs and is more complicated than the traditional grammar dichotomy: transitivity versus intransitivity. It is a lexicogrammatical system that plays a role in the realization of ideational meaning, both the logical, whose concern is representing how clauses are joined together to form sentences and paragraphs, or the experiential whose concern is representing experience .

In order to tackle transitivity system and its components in a text within SFL, an analysis of the processes, participants and circumstance is carried out.

There are six types of process which are: material, mental, relational, behavioural, verbal, and existential .Verbs of doing or actions and events are termed material processes. While verbs containing feelings, perceptions, cognition, and consideration constitute the processes of sensing are termed mental processes. Verbal processes, on the other hand, include verbs of saying , reporting, telling, etc. Relational processes, however, include verbs indicating circumstantial or possessive relations. And behavioral processes which subsume physiological and psychological behaviour processes. Finally, there are existential processes that entail verbs indicating existence.

\section{Coronaviruses}

Coronaviruses are zoonotic disease that a group of related RNA viruses cause in mammals and birds. In humans, these viruses cause respiratory tract infections that can range from mild to lethal. Mild illnesses include some cases of the common cold (which is caused also by certain other viruses, predominantly rhinoviruses), while more lethal varieties can cause SARS, MERS, and COVID-19. Symptoms in other species vary: in chickens, they cause an upper respiratory tract disease, while in cows and pigs they cause diarrhea. There are as yet no vaccines or antiviral drugs to prevent or treat human coronavirus infections. ( $\mathrm{Hu} \mathrm{Z}$, Song $\mathrm{C}, \mathrm{Xu} \mathrm{C}$, et al)( Dong Y, Mo X, Hu Y, et al.) (Giacomelli A, Pezzati L, Conti F, et al)

Coronaviruses were discovered in the 1960's, and the first viruses detected were chicken bronchitis and two nasal cavities for human patients with a cold called HPV 229E and OC43. 
Since then other elements of this family have been identified including: virus SKS in 2003, SK NL63 in 2004, HKU1 in 2005, SK virus in 2012, and the new SK 2019-nCoV. Most of these viruses have a role in causing serious respiratory infection, At the end of the year 2019, specifically in the month of November, the new Coronavirus COVID-19, which means corona virus disease 2019, appeared in the Chinese city of Wuhan and spread to various countries of the world. (Cai J, Xu J, Lin D, et al.) (Wu Z, McGoogan JM.,2019).

The name "coronavirus" (Arabic: Corona virus. CoV) is derived from ( Latin: corona) and (in

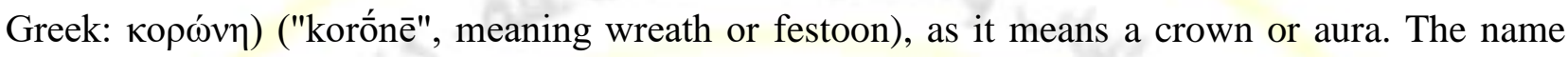
refers to the distinctive appearance of virions (the infectious form of the virus) that appears through an electron microscope, as it possesses fungi / villi of large bulbous superficial protrusion, showing them in the form of a king's crown or a solar halo. This formation occurs via the Follicular Fragments of the Viral Fork (S), which are proteins that fill the surface of the virus and determine host extraction. (Guan WJ, Ni ZY, Hu Y, et al) (Li Q, Guan X, Wu P, et al)

\section{4-1 Symptoms}

People with COVID-19 have had a wide range of symptoms reported - ranging from mild symptoms to severe illness. (Lauer SA, Grantz KH, Bi Q, et al.) (Chen N, Zhou M, Dong X, et al) (Huang C, Wang Y, Li X, et al.) (Chan JF, Yuan S, Kok KH, et al)

Symptoms may appear 2-14 days after exposure to the virus. People with these symptoms may have COVID-19:

- Fever (83-99\%)

- Cough $(59-82 \%)$

- Fatigue (44-70\%)

- Anorexia (40-84\%)

- Shortness of breath (31-40\%)

- Sputum production $(28-33 \%)$

- Myalgia (11-35\%)

Children have similar symptoms to adults and generally have mild illness. 
This list is not all inclusive. Other less common symptoms have been reported, including gastrointestinal symptoms like nausea, vomiting, or diarrhea. (Pan L, Mu M, Ren HG, et al.)

\section{4-2 Investigational Therapeutics}

No FDA-approved drugs have demonstrated safety and efficacy in randomized controlled trials for patients with COVID-19. Use of investigational therapies for treatment of COVID-19 should ideally be done in the context of enrollment in randomized controlled trials. Several clinical trials are underway testing multiple drugs with in-vitro antiviral activity against SARS-CoV-2 and/or immunomodulatory effects that may have clinical benefit. (Wang D, $\mathrm{Hu} \mathrm{B}, \mathrm{Hu} \mathrm{C}$, et al.) (Xu XW, Wu XX, Jiang XG, et al.) (Yang X, Yu Y, Xu J, et al.)

\section{ANALYSIS AND DISCUSSION}

This analysis aims at identifying how transitivity choices are made in a sample report in Aljazeera in order to find out the ideological motivations behind choices .The analysis data indicates that the report uses various types of processes to serve its ideology concerning coronavirus. In table (1), a sketch of these processes is introduced.

Table 1. Process types and their frequencies in the Arabic text

\begin{tabular}{|l|l|l|}
\hline Process & Frequency & Percentage \\
\hline Material & 17 & $68 . \%$ \\
\hline Relational & 5 & $20 . \%$ \\
\hline Behavioural & 2 & $8 \%$ \\
\hline Existential & 1 & $4 \%$ \\
\hline Total & 25 & \\
\hline
\end{tabular}

The following analysis of the selected text will explore the ideational meaning as regards what ideological aspects are involved in it. This will comprise the three process types most frequently used in the text(i.e. material, relational and behavioural processes).

\subsection{Material processes}


As shown in table (1), the processes more commonly used in the report are the material ones. This can be explained as being normal and expected as the main actor in the text is a novel disease of which little is known and whose impact on humans` health and the various aspects of their life has remained obscure as the virus`s nature and effects require much time to be uncovered .Hence the language of the text should replicate and reflect the real character of the disease to audience.

Besides, this forceful imaging of the disease is fairly needed as the researcher believes that Aljazeera adopts an ideological stance towards the novel virus as it is, indeed, having an ideology that is in harmony with the well-known mass media in America and Europe and the common mood of their governments. It is, therefore, creating an exaggerated representation of its effects and outcomes. Hidden ideologies, it could be argued, are responsible for the state of confusion and anxiety overwhelming the world resulting from the manner mass media are approaching the issue of covid-19.

Besides, the frequent use of the material process type reflects Aljazeera`s preoccupation to acquaint its audience with this newly emergent virus they are unfamiliar with and with its effects. Hence more attention is paid to covering the virus actions, the events related to it and the participants to them. Although, the main focus of the selected text is placed on showing the damages and losses inflicted, the risks it causes to people and to their body organs, the symptoms and how it can transmit among people and enter their body cells.All the above mentioned points are medical details which are useful and necessary for people to know about, yet most clauses of the report tend to present coronavirus as a powerful actor before whom the whole world`s governments and health institutions are powerless and helpless.

By foregrounding coronavirus, the effects it brings about and making it the focus of the report, the aim of that, it seems ,is to depict it as undefeatable agent whose health- devastating nature and serIous influence must be realized and recognized.

Additionally, coronavirus has also been presented as an influential actor of material processes in some clauses that are not concerned with the medical accounts of the disease or with the coverage of its nature or effects.. We find in the text, for instance a reference to the problem of ethnicity as the title of the report indicates. 
The title is constructed in the form of a question that asks if the virus was racist .Obviously, the writer here wants to remind his audience of the social and political injustice dominant in our world. The report looks as an opportunity for the writer and surely the channel to express the ideology they uphold about racism through pointing out and associating the terrible effect the virus causes with one of the most hateful political and social practices(i.e. racial segregation)still prevalent in many parts of the world. It is an attempt on the part of Aljazeera to compare the ugly picture of the virus with another ugly picture of racism, so, amplifying and strengthening the negative impression of the audience of this weird incomer.

More often than not, coronavirus has been located in an actor`s position in every material process occurring in the text. The inclusion of figures about those victimized by the virus and the multitude of complications, dangers threatening human lives and the mortality rates in China and the world all function as a means for spreading fear and caution among which, as had already been mentioned, some represent the role ascribed to the channel, its staff of reporters, correspondents, editors etc. and it is thus entitled to play .

To sum up, Aljazeera goes beyond giving objective unbiased account of the disease and its impact, to giving further details that seem to conceal its ideological stance and general policy .

The report begins with a question that seems at first glance irrelevant or abrupt as it questions the racial nature of the virus an implication that carries some ideological imprint. The verb type is relational and it is intended here as it seems to me, to ascribe a bad quality to the actor to exacerbate its already bad image and to exclude or cover up the real presupposed actor which according to prognostications and accusations China or America in whose labs the virus was manufactured as is shown in (1).

1-Hal[QA] vairus korona Kovid -19[Actor+ Pr] 'unsurī ?

Is Corona virus racist?

The same material process is embedded in another verbal process by the president office as in (2).

2. -Ma'a nihāiat 2019[Cl], kānat[Pr] al- bashariyah[actor] 'alā maw'id[Cl] ma'a 'adwā ghar $\overline{1}$ ba[Actor] bada'at[Pm+ actor] fi suq al-ḥaiwānāt al- baḥriyah[Cl] fi madeenat wuhān[Cl] fi al$\operatorname{seen}[\mathrm{Cl}]$. 
-With the end of 2019, humankind was doomed to meet a strange infection which began in the seafood market of the city of Wuhan , China.

It is observed that the word 'adwā gharība (a strange infection) is the actor in the clause followed by a material process verb type Which frequently occurs in various expressions across the text. The repeated use of material processes is meant to convey the powerful effect of the strange infection referred to .The case is quite obvious in (3) where more material processes are included in the clauses.

3-Thumma 'intashrat[Pm+actor] saree'an[Cm] fi kuli makān[Cl] li tu'athir[Pm+actor] 'alā 'ālaminā 'aklinā wa shurbinā wa safariinā wa 'ādatinā al- 'ijtimā'iyah[Cx] kamā 'atharat[Pm+actor] 'alā al- 'iqtisād al-'ālami[Goal] bi-rumatihi[Cx].

-Then, it spread out quickly everywhere to have impact on our world, food and drink,travel and social behaviours, it had also its influence on the world economy as a whole.

The same actor mentioned is maintained as the actor of a number of subsequent clauses as in (2) and (3) where the actor is the same but followed by a number of different material process verbs that include, bada 'at(began), 'intashrat(spread out), tu'athir(have impact) .

The sequence of material verbs is not random but is intended to illustrate the repercussions of the disease all over the world and its clear impact and powerful action .Furhermore, there is also a set of different types of circumstances used in the clauses in order to give a fuller account of the virus`s broad effect on human health and activities. These include: fi suq al-ḥaiwānāt albaḥriyah $[\mathrm{Cl}]$ fi madeenat wuhān[Cl] fi al seen $[\mathrm{CM}]$ ( in the seafood market of the city of Wuhan , China.) saree'an[Cm] fỉ kuli makān[Cl]( quickly everywhere), 'alā 'ālaminā 'aklinā wa shurbinā wa safariinā wa 'ādatinā al- 'ijtimā'iyah[Cx] (on our world, food and drink,travel and social behaviours), 'alā al- 'iqtisād al- 'ālami[Goal] bi-rumatihi[Cx] (on the world economy as a whole).

The excessive use of these different kinds of circumstances aims to give more details and demonstrate the vast amount of chaos and perplexity dominating the world around the development of the disease and the paralysis it brought about . 
More details about the tremendous effect of the virus is stressed in the clause complex (4). 4. Wa haithu 'ana 'a dād al- musabeen wa al- qatlā[ Actor] min hathihi al- jā' iḥa[Range] mā zāla yadūr[Pm] fa- ' inna al- 'āthār al- salbiyah[actor] al- mutaratiba 'alā al- Madā al- ba'eed[Cl] mā zālat[Pr] qaid tanabu' $\bar{a} t[\mathrm{Cm}]$. .

-Since the number of this pandemic`s infected and dead people is still increasing, negative effects on the long term are still based on predictions.

In this complex , two circumstances are used to add further details about the virus, the first one is a circumstance of location 'alā al- Madā al- ba 'eed- on the long term// and the second is a circumstance of manner qaid tanabu'āt- still based on predictions .

Thus, the material clause mā zāla yadūr- is still increasing// which consists of the adverb stillmā zāla//and the process yadūr-run// is understood as a clear indication of the deteriorating situation of the disease a clear evidence of the gloomy future concerning the number of infections.

5. Wa yarqud[Pm] fi ḥālatin ḥarija[Cm] ḥattā al-laḥdha[Cl] akthar min 75 alfan mimā majmū 'ihi thalāthat malāyyeen musaab[Goal] wifqan li-mawqi' worldmeters[Cx] .

-According to worldmeter website, more than 75 thousand of a toatal of three million patients lay in hospitals in critical conditions.

In the clause complex (5), which is a completion of the elaboration on the numbers of cases, there is a set of circumstances that show how so many people are afflicted with the disease. Here the report cites a well-known site to give some sort of credibility to the figures given and reliability to the channel's account and form a kind of a crutch to be lent on.

The report gives further defining details of the virus, using the material process in (6). 6. - wahwa[Actor] yantamee[Pm] 'ila 'â'ila mina al-vairūsāt al-tājiyah[Cx] 'aw mā yuta'āraf[Pme] 'alaihi beina al-nās[Cl] bi-ism Corona wa yantaqil[Pm+Actor] min shakhs liākhar[Range] 'an tareeq al- 'adwā al- mubāshira mina al- majāri al- tanaffusiyah[Cl] shabeehan bi- 'aqrānihi vairūsāt al-inflawanza[Ca].

- It belongs to a family of corona viruses, or the common name known by people, corona, and it transmits from one person to another by means of direct infection from the respiratory tract in the same way its counterpart influenza viruses do. 
In (6), there is a clause complex in which coronavirus is introduced as an actor. The material process yantaqil-transmit // is followed by the range min shakhs li-ākhar- from one person to another// is a message to people that the virus can transmit from one person to another easily , 'an tareeq al- 'adwā al- mubāshira mina al- majāri al- tanaffusiyah- by means of direct infection from the respiratory tract// which is a circumstance of location followed by a second circumstance, but of accompaniment this time ,shabeehan bi-'aqrānihi vairūsāt al-inflawanza- in the same way its counterpart influenza viruses do// .

The excessive use of all types of circumstances in this segment of the report and all over it serves in providing sufficient account of activity of the virus and the way it acts, transmits and has its impact on the victims so it is a call upon audience to take prevention precautions and realize the possible means and practices through which the virus can transmit a message which while acquaint the audience with the true nature of the disease it also serves in transferring the ideological implications upheld by the Aljazeera of creating a state of confusion and bewilderment for the Arab audience. In sum, the message indicates that the virus is deadly and can spread out easily.

Afterwards more material processes are used in , (7), (8) and (9) to describe the medical aspect of the topic which are normally the concern of doctors and scientist, not the ordinary people. The report at this juncture begins to provide citations that give details about the virus and its activity inside the human body along with material process that support the destructive effect of the disease .Whereas in (9), the clause complex revisits the introductory title question about the racism of the virus through asserting the rhetorical question made .

The answer shows that the virus victimized both blacks and whites alike in Texas, America and Britain a choice made to remind the Arab Audience of the racial discrimination system that dominated the world in general and the western countries in particular. Here, Britain and Texas in America are symbols and indirectly reminiscent of the racial practices the two countries had in the past and some cultural and social practices related to it still hold in the two countries despite the repeated claims of winning the battle against it.

Similarly, what is alluded through the comparison between the virus 's racial conduct and racial discrimination system is meant to further show the malicious behaviour of the virus and make its image more detested and fearful in the minds of the Arab audience as Arabs and 
Muslims in the region have suffered a lot of the hegemony, tyranny, and the political, cultural and economic interventions and exploitation of the western countries and America and their injustice towards the Arab and Islamic issues .

7. - Wa fi khidammi al-sa'i al- hatheeth li- ma'rifat 'āliyat dukhūl al-vairūs li-khalāyā al'insān[Cm] adhharat[Pme] dirāsa[Actor] nushirat[Pm] fi majalat al- tabee'a al- marmooqa[Cl] 'ana covid 19[Actor] yadkhul[Pm] al- khalaiyah[Goal] 'an tareeq al-' irtibāt bi- mustaqbil broutini 'alā satih al- khalāiā[Cm] yusamā[Pv] al- anzeem al- mouhawil li- 'angiotensin2[Goal] .

-In the pursuit of the running effort to identify the mechanism through which the virus can enter the human cell, a study published in the class journal, Al- Tabee`a, showed that covid19 enters cells through associating itself with protein receptor that exists on cell's surfaces tremed angiotensin2-converting enzyme.

8. - Wa hāthihi al- ma lumāt wa ghairihā[Actor] nabahat[Pme] al- bāhitheen[Goal] 'ilā darūrat al- akhth bi- al- itibār[Ca] ina mardā al- kilā[Actor] mathalan qad yahtājun[Pm] 'ināiya 'idāfiya[Goal] li- iftirad 'ana al-' isāba bi- covid-19[Cc] qad tu'athir[Pm] mubāsharatan[Cm] fi kafā'at 'amal al- kilyatein[Cl].

-And these information and others brought researcher`s attention to the importance of taking into account that patients with problems in lungs for example may need additional care for infection with covid 19 may have a direct effect on the efficiency with which lungs work.

9. Fi maqāl[Cl] nushira[Pm] 'alā BBC Future[Actor] bi-qalam Kristeen Ro[Actor], tabaiyana[Pm] 'ana vairūs corona,covid 19[Actor] qad 'asāba[Pm] wa qatala[Pm] min al-sūd[Cx] 'akthar mimā 'asāba[Pm] wa qatala[Pm] min al-beedh[Cx] fi Texas wa Breetanya[Cl].

In an article published in BBC Future by Kristen Ro, it was shown that corona virus, covid 19 has infected and killed blacks more than whites in Texas and Britain .

\subsection{Relational processes}

A relational process indicates a state or a process of being. It shows attributes and identify relations .It is used for describing people and things. In our text, relational processes come second within the group of processes and its percentage of occurrence is $20 \%$. This indicates that a noticeable percentage of the text is concerned with giving sufficient account of the participants attributes and distinctive features and identifying its nature. This, it can be argued, refers to the 
fact when a news text or article tackles/ covers some scientific issue, a good deal of focus is placed on providing facts about things, actions and phenomena. Hence, it is often the case we come across a frequent use of relative process in such texts to provide the attributes, information and distinctive features involved .Relational process occurring in the text are used to provide the audience with knowledge about the abrupt appearance of the virus in China. The place of the virus`s appearance or similar information about it are frequently given through the use of attributive processes as can be seen in (10).

10 -Ma'a nihāiat 2019[Cl], kānat[Pr] al- bashariyah[actor] 'alā maw'id[Cl] ma'a 'adwā ghariba[Ca] bada at[Pm+ actor] fi suq al-ḥaiwānāt al- baḥriyah[Cl] fi madeenat wuhān[Cl] fi al$\operatorname{seen}[\mathrm{Cl}]$.

-With the end of 2019, humankind was doomed to meet a strange infection which began at the sea food market of the city of Wuhan in China.

In (10), The virus is related to its description by using the relational process, i.e. , the virus is the carrier and the rest segments of the text provide the distinctive information about the virus .

While the complex of attributes mentioned in (11) contribute to the effort of amplifying the threatening image of the virus through a sequence of attributes that serve the function of creating a feeling of fear and anxiety among audience as to the mysterious and totally unknown nature and effects of this virus.

11. Laqad kānat[Pr] al-mahamma[Actor] al-kabeera al-mulqāt 'alā 'ātiq al-' ūlamā[Cm] hiya ma rifat wa tashkhees wa dirasat[ Attribute] hātha al- vairus[Carrier].

-The great responsibility resting on the shoulders of scientists has been knowing, diagnosing and studying this virus.

Then, a similar clause is given statement in (12), where coronavirus is presented as a carrier and li 'ana ladaihim kamiyah 'aqal min hātha al-'inzeem- because they have lesser amounts of this enzyme// is the attribute.

12. Hal hunāk $[\mathrm{Cl}+\operatorname{Pr}]$ basharun[Actor] muhasanun tabee'iyan dhida vairūs corona , covid 19[Carrier] li'ana ladaihim kamiyah 'aqal min hātha al- inzeem[Attribute] ?

- Are there humans naturally immune against corona virus, covid 19 because they have lesser amounts of this enzyme? 
The aim behind the use of Intensive identifying relational processes is setting up an identity, role or meaning// (Butt et al. 2001: 59) and they are recurrently used in the text as is the case in (13).

13. - 'utliqa[Pm] 'alā hātha al-vairūs[Identified(IFD] 'ism " sars couv 2"[ Identifier(IFR)].

-This viruse was called " sars cov 2".

In (13), in addition to the diversity of identifying terms of the virus, coronavirus is granted a new name to identify it with a further name as " sars couv 2"

\section{3. behavioural processes}

Behavioural processes represent a semantic " cross between material and mental processes"(Machin and Mayr,2012:109).They are partly about action but the action in their case" has to be experienced by a single conscious being" (ibid.). In (14) and (15), the virus is personified and animated allegorically may be to conceal the real agent who manufactured it that according to a considerable number of mass media report, it could be China, America and to lesser extent France and is part of some international political or economic game within the conflict between superpowers.

The actor of the clause in Arabic is the virus // and the behavioural verb is yakhtar- choose. Here, the writer points out that the racial accusation made in the title does not exist, rather, the victims of the virus are naturally the poor classes which suffer from negligence and deprivation of basic human rights. The clause includes some protest or condemnation to inequality dominating the world where only rich people have access to all material and moral needs and alluding to the political and economic systems in the world the real party responsible for this inequality and social economic gap.

14. Wa lakinahu [ Actor]lam yakhtar[Pb] dahayah[Goal] bina`an `ala lawnihim [ $\mathrm{Cx}$ ] bal kana ‘istihdafahu li-alfi`ah al- `akthar tahmeeshan wa al- `akthar faqran wa rubama al-`aqalu husulan alar i`aya tibbiyah.

-But it did not choose its victims based on their colour, rather, it targeted the most poor and marginalized social class , and perhaps the least priviledged class to receive medical care. 
15. 'Inna vairus Kourona (Covid-19)[Actor] la yufariqqu[Pb] beina `irq wa `akhar[ $\mathrm{Cx}]$, huwa qatilun raheemun li-`ayyi fi`atin da`ifatin mana`iyan `aw lam talqa `inayatin tibbiyatin mula ima.

-Coronavirus does not differentiate between one ethnicity and another, it is a merciful murderer of any immunity weak social class or any people lacking appropriate medical care.

\section{6- Lexical Choices}

What is emphasized through Lexical choices is how powerful the speaker is (Van Dijk ,2006a: 376) . In our sample text, coronavirus in the first place is the main participant of many clauses. Mostly, coronavirus is represented as an actor but there are some clauses in which it is represented as a goal, an agent in a relational and a behavioural processes through which interpersonal meanings are realized.

A plethora of lexical items are used to characterize and name coronavirus, a case termed overlexicalization with some intended purpose of magnifying its image and power and creating a specific emotional and behavioural effect. It has been variously described as 'adwā(infection)//once, jā'iha(pandemic)//twice, marad(disease)twice,vāirus(virus) 10 times ,Kouronā (corona)// twice ,covid19// 6 times,sars cov2// once ,vāirus influenzā (influenza virus)// once, al-vāirus al-tāji(coronavirus)// once , vāirus korounā(coronavirus) // twice .

These synonymous terms ,referring to the same referent(i.e. cornavirus) are largely used in Arab mass media in reference to the disease. The aim of this wide variety of lexical items in reference to coronavirus is to present it as a powerful agent and to increase the level of negative connotations associated with the different terms attributed to it but first of all to conceal some ideological maneuver in this case which involves hiding the real actors behind the pandemic .

Besides, this tendency reflects the vague and undetermined nature of the disease being a novel virus and much time and effort are needed to reach enough findings about it, preparing medicines and finding vaccines for it.

This lexical variance and the boundaries of topics are determined in advance even when there is variation in persons`and newspapers`description of the same people or objects (Van Dijk,2013: 75). No indication or representation in the text gives any prospect of hope and certainty about the current situation created by the disease and the report draws a dark picture of it. The writer 
avoids any mitigating lexis to describe the disease and its outcomes. The report tends to convey powerful and exaggerated meanings through the lexical choices made to maintain an already alarming image of it in the world mass media.

Coronavirus is foregrounded as an actor across the text through the material processes opted for. For instance, the disease `athara-had impact// on our world, food and drink, travel and social behaviours, and its influence came to include the world economy as a whole, sabbaba -caused // breathing difficulty to around $14 \%$ of the patients. patients infected 'ānu// suffered from the disease and the virus qad qadā-has killed// $6.5 \%$ of the patients in China etc.The dangerous and human activity paralyzing effect of the virus which dominates the minds of the channel's audience is preserved and reinforced in the report.

In spite of the clear exaggeration of the novel disease by the report, which is based on ideological foundations and represents an undesired intervention running against the ethics of unbiased and honest mass media, highlighting the dark picture of it, provides plenty of benefits to audience as this motivates them to take health precautions such as social distancing, wearing masks and gloves when in contact with other people and the use of disinfectants . Additionally, such reports are a good means through which the Arab public can raise their awareness and glean information that assist them in tackling the medical, social and economic problems caused.

\section{CONCLUSION}

The study concludes that:

1- The most frequently used type of processes by Aljazeera's report is that of the material processes in order to explicate the actions of coronavirus and the events caused by or related to it being the major actor and agent in the text.

2- The majority of clauses in the report are devouted to the description of the nature of the virus, its effects and what influences it brought about since its appearance as well as figures of its victims. This tendency on the part of the writer and the channel is natural and fairly expected because they are entitled to give lucid account of the disease and its attributes and symptoms since the subject of the text is a medical one based on medical findings and reliable sources.

3- The text is characterized by the frequent use of attributive and identifying relative processes which corresponds to the goal of the coverage that involves describing participants. 
The sample text also contains 5 clause with relational process when it comes to establishing a fact or a finding about the virus and 2 behavioural processes when the actor is animated for rhetorical purposes in addition to one existential process .

4- A clear intentional selectivity in discourse structures by the writer of the report is observed not for expressing his personal feeling or impression of the disease, rather to draw the audience attention to its massive workings and effects on their life and social and economic activities.

5- Coronavirus is constructed in an exaggerated way and made the focus and focal point in the report so as to inform the Arab audience of the hazardous effects of it and the alarming repercussions it created. Hence, the curiosity of the audience is satisfied along with a dissemination of the ideological implications intended which involve exaggerating the image of the virus a matter that complies with the general mood prevalent in the major superpowers` media that tend to create the same exaggerated image to their audience for some hidden political and/ or economic agenda.

\section{REFERENCES}

-Butt, D., Fahey, R., Spinks, S. \& Yallop, C. 2001. Using Functional Grammar: An

Explorer's Guide. Sydney: Macquarie University.

- Cai J, Xu J, Lin D, et al. A Case Series of children with 2019 novel coronavirus infection: clinical and epidemiological features. Clinical infectious diseases : an official publication of the Infectious Diseases Society of America. 2020.

- Chan JF, Yuan S, Kok KH, et al. A familial cluster of pneumonia associated with the 2019 novel coronavirus indicating person-to-person transmission: a study of a family cluster. Lancet (London, England). 2020;395(10223):514-523.

- Chen N, Zhou M, Dong X, et al. Epidemiological and clinical characteristics of 99 cases of 2019 novel coronavirus pneumonia in Wuhan, China: a descriptive study. Lancet (London, England). 2020;395(10223):507-513.

-Dong Y, Mo X, Hu Y, et al. Epidemiological Characteristics of 2143 Pediatric Patients With 2019 Coronavirus Disease in China. Pediatrics. 2020. 
-Fowler, R. 1991. Language in the News: Discourse and Ideology in the Press. London: Routledge.

-Guan WJ, Ni ZY, Hu Y, et al. Clinical Characteristics of Coronavirus Disease 2019 in China. The New England journal of medicine. 2020.

- Giacomelli A, Pezzati L, Conti F, et al. Self-reported olfactory and taste disorders in SARSCoV-2 patients: a cross-sectional study. Clinical Infectious Diseases. 2020.

Haig, E. 2011. Ideological aspects of ideational meaning: A study of process type usage in a radio news bulletin about youth crime. Studies in Media and Society, 3, 19-44.

Halliday, M. A. K. (1978). Language as Social Semiotic: The Social Interpretation of Language and Meaning. Edward Arnold: London.

—. (1994). Functional Grammar. London: Edward Arnold.

------(2000). An Introduction to Functional Grammar. Foreign Language Teaching and Research Press.

—_ \& Matthiessen, C. M.I.M. (2004). Introduction to Functional Grammar. London: Edward Arnold.

- Hu Z, Song C, Xu C, et al. Clinical characteristics of 24 asymptomatic infections with COVID19 screened among close contacts in Nanjing, China. Science China Life sciences. 2020.

- Huang C, Wang Y, Li X, et al. Clinical features of patients infected with 2019 novel coronavirus in Wuhan, China. Lancet (London, England). 2020;395(10223):497-506.

- Lauer SA, Grantz KH, Bi Q, et al. The Incubation Period of Coronavirus Disease 2019 (COVID-19) From Publicly Reported Confirmed Cases: Estimation and Application. Annals of internal medicine. 2020.

-Li Q, Guan X, Wu P, et al. Early Transmission Dynamics in Wuhan, China, of Novel Coronavirus-Infected Pneumonia. The New England journal of medicine. 2020. 
- Machin, D and Mayr, A. (2012).How to Do Critical Discourse Analysis. London: Sage.

Matthiessen, C. M.I.M. (1995). Lexicogrammatical Cartography: English Systems. Tokyo, Taipei and Dallas: International Language Sciences Publishers.

-Pan L, Mu M, Ren HG, et al. Clinical characteristics of COVID-19 patients with digestive symptoms in Hubei, China: a descriptive, cross-sectional, multicenter study. Am J Gastroenterol. 2020; [Epub ahead of print].

-Van Dijk, T. A .(2006). Discourse and manipulation. Discourse and Society, 17/3, 359-383.

—. (2013) . News as Discourse. London: Routledge.

- Wang D, Hu B, Hu C, et al. Clinical Characteristics of 138 Hospitalized Patients With 2019 Novel Coronavirus-Infected Pneumonia in Wuhan, China. Jama. 2020.

- Wu Z, McGoogan JM. Characteristics of and Important Lessons From the Coronavirus Disease 2019 (COVID-19) Outbreak in China: Summary of a Report of 72314 Cases From the Chinese Center for Disease Control and Prevention. Jama. 2020

- Xu XW, Wu XX, Jiang XG, et al. Clinical findings in a group of patients infected with the 2019 novel coronavirus (SARS-Cov-2) outside of Wuhan, China: retrospective case series. BMJ (Clinical research ed). 2020;368:m606.

- Yang X, Yu Y, Xu J, et al. Clinical course and outcomes of critically ill patients with SARSCoV-2 pneumonia in Wuhan, China: a single-centered, retrospective, observational study. The Lancet Respiratory medicine. 2020.

$\mathrm{P}=$ Process $; \mathrm{Pm}=$ material process $;$ Pme $=$ mental process $; \mathrm{Pv}=$ verbal process $; \mathrm{Pr}=$ Relational processes, $\mathrm{Pb}=$ behavioural process, $\mathrm{C}=$ Circumstance $; \mathrm{Ca}=$ accompaniment $\mathrm{Cc}=$ cause $; \mathrm{Cl}=$ location; $\mathrm{Cm}=$ manner; $\mathrm{Cx}=$ extent. 